\title{
MEDIA ROLES IN ISLAMIC CONVERSION: A STUDY IN SABAH, SARAWAK AND BRUNEI
}

\author{
Salinayanti Salim \\ Universiti Brunei Darussalam \\ (salinayanti@gmail.com) \\ DOI: https://doi.org/10.22452/brj.vol12no1.1
}

\begin{abstract}
This paper examines the roles of media in the conversion of the Muslim converts in Sabah, Sarawak and Brunei. The media involved are traditional media and social media. The data was collected through one-on-one interviews with the Muslim converts who resided in Sabah, Sarawak and Brunei. The data was then analysed using descriptive and interpretive approaches. The findings were categorised into two major themes which represented the overall responses of the informants towards the roles of media in Islamic conversion, the media roles in the time of conversion, and the types of media used in the conversion. The findings reveal that the media played roles in the conversions of all the informants in the study. The roles of media and their uses in the time of conversion are quite similar in the Sabah and Sarawak findings, whereas there is a significant difference in the Brunei finding. As for the types of media, traditional media have more important roles in Islamic conversion in Sabah, Sarawak and Brunei.
\end{abstract}

Keywords: traditional media, social media, Muslim converts, Islam, conversion

\section{Introduction}

Islam, unlike Christianity, was rarely discussed by the mainstream media until several decades ago. After the violent event of September 11, 2001, Islam has been a contested subject in the mass media all over the world. The search on Islam since then has increased because people are trying to understand the religion and the motives behind the purported Muslim plane hijackers' actions. However, as a result of the attack, the fear of Islam or also known as Islamophobia has alarmingly increased, specifically in the West and other non-Muslim countries. Even though Islamophobia has a long historical root, the tragedy of the 9/11 attack has triggered 
the mass media to give bias reports, thus multiply the negative perceptions towards Islam (Esposito \& Kalin, 2011, p. xxiii).

On the other hand, the growing attention paid by the media has resulted in Islamic resurgence. Religious broadcasting has moved from the margins of social and religious life to centre stage (Hoover, 1988, p. 12). It is in line with the advancement of technology where the roles of the media have also been expanding more interactively. Seeing it as an upper hand, the Muslims utilise the media, in their attempts to introduce the positive image of Islam to a larger community. The movement is called Islamic da'wah ('da'wah' henceforth).

\section{Past Studies on Media Roles in Disseminating Da'wah in Malaysia and Brunei}

The role of the media today is to break the barrier between these two communities by providing a larger platform of Islamic knowledge for the seekers. In Malaysia, Fadzli Adam, Marhana Mohamed Anuar and Ab. Hamid Ali (2014, p. 74) agreed that the Muslim community should learn and master the technology and use it to conduct research, particularly on Islam, so that they will be able to distinguish right from wrong.

The advantage of social media that traditional media do not possess is that all Muslims are capable of imparting the knowledge of Islam. As stated earlier, with more Muslims taking part in carrying out da'wah in the media, more people including the non-Muslims are learning about Islam voluntarily. Umar Halim and Samsudin A. Rahim (2010, p. 123) stated that it is easy with all the Islamic websites which the users can access to download information they need, and social media make the access easier by displaying the links of the websites above on the social networking sites. The Malaysian government has also given full support in spreading da'wah by establishing official websites with easy access to Islamic information and teaching (Fadzli Adam, Marhana Mohamed Anuar, \& Ab. Hamid Ali, 2014, p. 75). Another argument for social media is the act of conducting and receiving da'wah can appear to be more personal since most of them have an established rapport with one another. People are more comfortable with da'wah conveyed by someone they know because it involves deep emotion such as compassion and mercy (Muhammad Yusuf Khalid \& Wan Mohd. Fazrul Azdi Wan Razali, 2011, p. 41).

However, traditional media do attract a certain group of audience. Mohd. Adam Mahadi (2013, p. 18) found that there are some devout Muslims who prefer printed materials to virtual texts on the Internet when seeking knowledge on Sirah (history in the Arabic language). Even with social media on the rise, traditional media remain as credible sources of information. In terms of the authenticity of 
the news, Kovačič, Erjavec and Štular (2010, p. 117) discovered that traditional media are more reliable than online media. Additionally, Dr. Zakir Naik, a Muslim scholar, in his debate titled 'Media and Islam', sternly stated that television will always be the first medium in relaying the message of Islam. If there are people who say it is the internet, such opinion then needs to be re-examined (Badli Shah bin Alauddin, 2016, p. 23).

In Brunei, abundant texts pertaining to Islam and Muslims in traditional media have attracted many non-Muslims to learn about the religion and resulted in their conversion to Islam (Asiyah az-Zahra Ahmad Kumpoh, 2014, p. 169). It was reported that in the first two months of 2015, 67 people in Brunei converted to Islam and the number is increasing (Hassanal Harries, 2015). One of the contributing factors is the contextual environment where they live in an Islamic country. Asiyah az-Zahra Ahmad Kumpoh (2014, p. 167) stated that another attraction to Islam is familiarity with Islamic practices such as fasting. During the month of Ramadhan (fasting month in Islam), there are many television programmes specially produced relating to Islam and fasting such as forums and drama series which is also a similar situation in its counterpart, Malaysia. Bruneians are encouraged to utilise the new media as a platform to disseminate accurate information about Islam as one way of doing da'wah (Rasidah HAB, 2012). Social media particularly are perceived as the convenient medium for the da $i$ (Muslim propagator) to promote Islam since it will reach the users in the shortest time.

\section{Past Studies on Media Roles and Muslim Converts}

In a book titled British Muslim Converts: Choosing Alternative Lives, Kate Zebiri wrote that the rise of the internet has had a significant impact on Muslim converts in Britain and worldwide (2008, p. 22). In social media especially, the information on Islam is ubiquitous and easily accessed. There is also a free space in social media where the Muslim converts can interact with each other or participate in open discussions and learn about the aspects of Islam (Zebiri, 2008, p. 22). Furthermore, the Muslim converts form their online community, in which the goals are to hold Islamic courses exclusive for the new converts, to cater to the needs of the members and to provide support for the members in sustaining their faith. Having the chance to be a part of a group gives the Muslim converts who were possibly disowned by their friends and family members because of their conversion (Osman Abdullah @ Chuah Hock Leng, 2006, p. 71), a sense of belonging, and reduce the sense of estrangement (Severin \& Tankard, 1979, p. 213). 
Meanwhile, traditional media such as television are also capable of providing a platform for the Muslim converts to feel that they belong in the Muslim community. For instance, an Islamic programme called 'Reflections' on a Malaysia television station, Al-Hijrah. It was hosted by an American Muslim convert, Imam Suhaib Webb. Webb's 'Reflections' television programme managed to garner a lot of offline audiences and was predicted to attract the audiences who were also Muslim converts, thus created a sense of belonging (Salinayanti Salim, 2018), or at least a sense of connection.

In this regard, even though there are a number of researches on media and Islamic da'wah, not many researchers focus on the roles of media in the lives of Muslim converts before their conversion to Islam. Hence, this study intends to fill the gap by examining the roles of media in the lives of Muslim converts in Sabah, Sarawak and Brunei prior to becoming Muslims.

\section{Theoretical Framework}

This study adopted the theoretical framework proposed by Stig Hjarvard where media are treated as the medium of religious change. Hjarvard (2008, p. 24) concluded that:

The developments are complex and do not necessarily have a uniform impact on religion; in some instances, media may further a resacralization of society, in others, they undermine the authority of institutionalised religion and promote secular imaginations, rituals and modes of worship. At a general level, these processes share a common feature: they are all evidence of the mediatization of religion.

Stig Hjarvard focused this theoretical framework on media uses in religion in general. The theory elaborated on the present timelines of the religious change that occurred among the informants. Other than that, the types of the media discussed in the Hjarvard's study were quite dispersed. Last but not least, Hjarvard's study was conducted in Denmark with a representative sample of the Danish adult population. On that note, this study intends to analyse the roles of media in Islamic conversion through four literature gaps. Firstly, this study focuses specifically on the religion of Islam and Muslim converts. This study did not include other religions or born Muslims. Secondly, the study aims to analyse the timelines of the Muslim converts' encounter with Islamic contents in the media prior to their conversions. Thirdly, this study seeks to examine and compare the types of media that were influential to the Muslim converts in their conversions. 
Finally, the study employed Hjarvard's framework in the context of Borneo, specifically Sabah, Sarawak and Brunei.

\section{Research Questions}

This study addresses the following research questions:

1.1 Did the media play roles in the Muslim converts' conversion?

1.2 What are the types of media used in the Muslim converts' conversion?

1.3 Which of the media are more significant in the Muslim converts' conversion?

1.4 What are the similarities and differences in the Muslim converts' conversion in Sabah, Sarawak and Brunei?

\section{Methodology}

Data for this study was collected through one-on-one interviews with nine Muslim converts in Sabah, Sarawak and Brunei respectively. The total number of informants is 27. The informants were all Muslim converts who lived or resided in the city areas of Sabah, Sarawak and Brunei. The informants comprised of both males and females of different age, educational and social backgrounds. Also, they were from different races and ethnicities as well as practitioners of different religions previously. The range in the informants' demographic profiles had resulted in newfound and interesting patterns. The interviews generally took about 45 minutes on average.

\section{Data Analysis}

The data gathered were then analysed using a thematic approach which was based on post-established themes, the media roles in the time of conversion and the types of media used in the conversion. The process of analysing incorporated two wellknown methodologies in the studies of a phenomenon, which are descriptive and interpretive approaches.

\section{Results and Discussion}

\section{The Role of Media in Islamic Conversion in Sabah}

In Sabah, some informants found the media essential as primary tools while others found it to be supplementary only. The types of media used mostly by the 
informants were books, followed by television and radio programmes. The result is expected after a cross-tabulation between their age group which ranged from 35-60 years old and their years of conversion which mostly occurred from the 1970s to 2000. During that era, social media such as Facebook, YouTube, Twitter, and blogs were either not available yet or not widely used. The only options for the informants were of traditional media like television, radio, books and newspapers. Despite a considerable number of media outlets, the Islamic materials then were limited except for books. Thus, it justifies why books were the main references for Islamic knowledge among most of the informants.

Another pattern discovered in the finding is the time when the media became impactful for the informants. A 37-year old manager of a religious body in Kota Kinabalu revealed that Islamic and religious books became his favourite reading after a Muslim queried him about his faith in Christianity:

\section{[Informant JS, Sabah]}

After that, I attended a university in Selangor. One day a female student was possessed. After the incident, I was discussing faith with my Muslim friend. His last question startled me. He asked, "Do you believe in your God?" Since then, I had gone to the library and bookstores to find books on religions. That is an advantage of being at a university. You get access to many books. So, I borrowed and bought books about Islam, Christianity and other religions. I read them carefully one by one. However, my main references were Quran and Bible... [trans]

During that time, he was an undergraduate at a public university in Peninsular Malaysia. He emphasised in the interview that the translated version of the Quran was the first 'book' he bought and he read every line curiously. He also extended his search for God's existence to other religions like Hinduism and Buddhism. In the end, the informant admitted that there are more similarities between the Bible and Quran than any other religious scriptures. In general, the books about Islam which he read extensively were the basic principles and practices in Islam. He was convinced of what he read in those books because qualified scholars wrote them. Even so, the books were seen as supplementary to him as he was more interested in face-to-face dialogues with a religious leader at his university, which eventually led to his conversion to Islam. This happened in the 1990s when other media outlets such as television, radio and the internet were also available. So, perhaps the informant chose hardcopy books over the other outlets because they were the most accessible media to him as a university student at the time. 
Meanwhile, marriage is a recurrent factor that led most of the Sabah informants to Islam. Nevertheless, the marriage did not seem like sufficient preparation for two housewives in this study. So, they started looking for religious books to strengthen their faiths in Islam:

[Informant KS, Sabah]

I read about Prophet Isa (Jesus) and about how his mother had to give birth to him alone and far away from people. That is the same story I read in the Quran. [trans]

[Informant C, Sabah]

I read this one book which compared Islam to Christianity, but I forgot its title. I had a clearer understanding and was more certain of becoming a Muslim. I was confused with Christianity because it hardly explains about the real God. [trans]

The first informant, Informant B said the book she had read before becoming a Muslim contained a story of Prophet Jesus (as) and his mother, Maryam. Although the story was also present in the Christian version in the Bible, the informant found more congruency when reading the Quran. She claimed that it reassured her in her decision to become a Muslim. On the other hand, Informant $C$ stated that she was interested in a book on religious comparison prior to marrying her husband. From both experiences, it seems that books acted as a support system to these informants' decision-making process in marrying Muslim men. The two books compared religions and this helped the housewives since they were already familiar with Christianity, so they used the knowledge and compared it with Islam. This further suggests that books aided their decisions in converting to Islam. Another pattern that emerged from the data is the influence the media had on the informants during their childhood years. For two female schoolteachers, the media sparked their interests in Islam when they were young. One of them listed two types of Islamic programmes on television which shaped her positive attitudes towards Islam in the early years:

[Informant EL, Sabah]

When I was small, I lived in a Chinese-populated village where people always gambled and spoke harshly to one another. I did not like that scenario. What I liked the most was what I saw on television. I liked the sound of adzan (call to prayer) and there was this Muqaddam programme. 
However, I was small then so I did not overthink of my interest. However, I did admire the way Muslims lived. [trans]

It is undeniable that the unpleasant occurrences she encountered had driven her to search for a life which she deemed more peaceful and disciplined. She turned to television as a result of inadequate real-life contact with Muslims except in school. For her, the sound of adzan was soothing to her soul even though she did not fully understand the meaning and purpose of it. There is a possibility that she compared the soft, melodious tone of the adzan caller to the harsh voices of the customers engaging in 'rude' conversations at her father's shop. Also, she might have seen the difference between the customers and the organised and obedient behaviour of Muslims who appeared in the programme Muqaddam. Muqaddam is a Quranic recitation programme with the scene of a religious teacher teaching several young students. Although it was not an ideal comparison since television programmes were orchestrated while the daily conversations of her father's customers were spontaneous, it still encouraged her to idolise the Islamic characters she saw on television.

Another informant, a 53-year old housewife, recalled her beautiful memories of listening to adzan through the radio when she was young:

\section{[Informant J, Sabah]}

I liked the sound of adzan and I used to listen to it many times on the radio. At first, I thought to myself, what is that song? It is not the same as the other songs I listened to. It is so beautiful and soul-stirring. I then asked my friend and she told me, it was a call to prayer for the Muslims, not for us. However, it did not change my perception. That was the early attraction I felt towards Islam. [trans]

Similar to the schoolteacher, Informant EL, growing up in a non-Muslim community made the housewife noticed what was uncommon and not a part of their original religious practices. Although she heard the adzan on the radio and not television because her family could not afford to buy one, it still encouraged her to learn further about Islam. However, she only preferred the adzan aired on the radio and not the live ones at mosques. This shows the strong quality of traditional media since the person who recorded the adzan was perhaps screened thoroughly through several auditions. Even though radios lack visual element and are only confined to sound, it is highly personal to the listener such as the informant (Stout, 2012, p. 89). At the age of 14, she already memorised the verses of adzan which is impressive since she was not yet a Muslim and she did not have 
any Muslim friends. She was able to do this due to the exposure to the adzan on the radio. Radio programmes in the 1970s-1980s did not contain a lot of Islamic segments, but the little exposure of adzan managed to give a huge impact on the informant's life. It is heart-warming to reflect on her experience because radios were and are still used generally for entertainment purposes. Despite the many Western songs she claimed she heard on the radio, a 2-minute religious call was the one that attracted her the most.

\section{The Role of Media in Islamic Conversion in Sarawak}

In Sarawak, the informants came into contact with Islam either through Muslims or media materials. In comparison with the Sabah data where marriage was the start of most informants' journeys of seeking Islamic knowledge, Sarawak informants treated their marriages as the 'final piece of the puzzle'. This means that they were considering converting to Islam and they have started the necessary preparations by mingling with Muslim friends. Consequently, they came into contact with traditional media by reading books and newspapers, listening to nasheeds (Islamic songs) and watching Islamic television programmes.

For a 54-year old informant, he was attracted to Islam due to early exposure to Islamic kitabs (books) during his school years. The informant stated that he was grateful to have found his Muslim-born wife and he believed that this was the final sign from God:

\section{[Informant N, Sarawak]}

Alhamdulillah, Allah sent someone who was already Muslim to be my wife. That is also a path to Islam. However, I had always liked Islam since I was in Form 5. My friends and I were studying the old kitabs and I learned a lot about Muslims' God from the kitabs. The old kitabs were easy to read because they were much thinner than the present kitabs. [trans]

Admittedly, his journey to conversion started when he encountered old kitabs in secondary school. Perhaps the descriptions of God in the kitabs fascinated and motivated him to learn more about Islam afterwards. Kitabs are Islamic printed books used as primary references in Islamic learning before the arrival of the internet. According to the informant who was also a religious teacher, the older kitabs were easily understood because they were not as thick as today's kitabs. The direct explanations in the older kitabs were presumably more suited to the understanding of a then 17-year old student. The informant also shared his interest and curiosity with his friends and this might have given him a better understanding of the kitabs' contents. 
Meanwhile, one informant confessed that her journey to Islam was experiential and it involved two traditional media outlets which are radio and books:

\section{[Informant NR, Sarawak]}

I remembered when I was in school; I used to listen to Quran recitation on the radio every night before they ended their airtime. I liked it so much. Another one was Takbeer Raya. However, that was it until I went to the US to further my study. I was a Roman Catholic follower. Every time I went to churches, they said I was at the wrong one. It was not like that in Sarawak. It turned out the churches in the US are racially segregated, the whites have their churches and the blacks have their churches. So I was cast out because I was neither. On Christmas day, I went to one church, but no one greeted me or wished me. I was really sad. Then I walked back home; I saw a mosque. People who came out of it were from different racial backgrounds and they hugged each other. It made me wonder, so I did my own research about Islam through books from the library and my American Muslim converts' friends. There were not many books about religions then. [trans]

The informant's early exposure to the recitation of the Quran was perceived as calming, even though she did not understand the meaning of the verses because they were in Arabic. The Quran recitation segment was only for a few minutes and it was broadcasted before the airtime was suspended for the day. Furthermore, the recitation was recordings of Muslims with sound voices which made it more cogent to the informant. The informant did not foresee herself becoming a Muslim until she had unpleasant encounters with some churches and a curious situation at a mosque in America. She borrowed religious books from the university library and compared a few religions until she was left with just Christianity and Islam. Finally, she embraced Islam after receiving strong encouragement from her American Muslim converts friends who also lent her more books about Islam. In this situation, books became the main references she needed before she decided to become a Muslim. It is assumed that books were the most readily available media at the time because the two informants were university students in the pre-internet era.

In some cases, indirect exposure to Islamic media texts can lead a nonMuslim to Islam. For example, a 31-year old housewife still remembered the Islamic songs she enjoyed listening to in her Muslim friend's car: 


\section{[Informant NL, Sarawak]}

I had many Muslim friends when I was young. They were from Sabah and Brunei. I had non-Muslim friends too, but I was more comfortable with my Muslim friends. When I was in my friend's car, she liked to put on cassettes of nasheeds I enjoyed listening to them. [trans]

The friendship with Muslim peers inevitably exposed the informant to several Islamic materials in the media and nasheed had the most impact on the informant. However, she did not perceive it as da'wah because the nasheeds were played in her friend's car, rather for entertainment. In other words, it was the choice of the Muslim friend and the informant was listening to them. The role of nasheeds here seemed supplementary since she had already been interested in Islam because of her Muslim friends.

As mentioned previously in the Sabah section, Islamic contents in traditional media were not as widespread as today. However, one Islamic programme left a strong impression on one informant, Muqaddam:

\section{[Informant T, Sarawak]}

Islamic contents in the media today are a lot, but they do not seem Islamic to me. Unlike this one programme I used to watch when I was small, Muqaddam. Honestly, I was not yet a Muslim, but I knew how to read in Jawi and recite Quran a little bit because of the programme. Back in my younger days, that was the only Islamic programme. Besides, not many people in my village owned a television set. I had to pay 20 cents each time I wanted to watch television. Since there were few in numbers of television channels, I had no choice but to watch Muqaddam which I eventually liked. [trans]

It could indicate the number of Islamic programmes in the media does not determine their quality and impact in the lives of Muslim converts. Muqaddam was a popular Islamic programme in the 1980s and it was one of the few Islamic materials on television, but it managed to attract the informant to learn about the Quran and Tajweed (rules on how to recite the Quran). He also admitted the knowledge he acquired from the programme helped in his conversion to Islam which was through marriage. His reaction was similar to the informant in Sabah (Informant EL) who also recalled how Muqaddam formed her positive perceptions of Islam. Both admitted that Muqqadam had a lasting impression on them than the Islamic programmes shown today. 
As for a 36-year old informant, she claimed her decision to convert to Islam was sudden and it was made after she watched several Malay dramas which depicted the lives of Muslims:

[Informant D, Sarawak]

I liked to watch Malay dramas because when they have problems, they have God to turn to. There is no need to share with people. It is like after solah (prayer), their problems would be lightened or resolved. [trans]

Although the informant said her conversion was rather quick compared to those who took time to weigh the pros and cons of their conversions, the researcher believes that the informant also had taken some time to think about her decision. She did not share it with the researcher perhaps because it was personal to her. Despite her willingness to be interviewed, her responses were terse and on point. The role of Malay dramas in the informant's conversion could be treated as the 'final push' she needed to strengthen her resolve to become a Muslim. Even though what was seen on the shows was not the epitome of reality, scenes, where the actor or actress interacted with God in prayer, they may have had a positive influence on the informant. She sought this relationship in Malay dramas because she knew it was difficult to find in real life.

\section{The Role of Media in Conversion in Brunei}

The patterns observed in the Brunei data regarding the role of media in Muslim converts' conversion is slightly different from those in the Sabah and Sarawak data. In general, the media only played significant roles after the Bruneians decided to embrace Islam. In other words, the Islamic contents in the media may not have been influential during their childhood and teenage years, as they were to the informants in Sabah and Sarawak. Upon further inquiry, the Brunei informants revealed that there were other more significant factors in their conversion. The media became important to the informants shortly after the informants were attracted to Islam which was triggered by their physical surroundings. The two most mentioned factors were personal encounters with Muslims such as family members and friends, as well as the educational institution.

One informant admitted that he chose to convert to Islam after he was invited continuously by his Muslim son:

[Informant AH, Brunei] 
I became a Muslim after my son convinced me to convert to Islam. I wanted to convert much sooner, but I did not want to upset my parents. When they died, I felt like I could convert because I would not hurt them anymore. Other than that, my workplace is surrounded by Muslim coworkers and I always watch them pray. [trans]

Persistent invitations by the informant's already Muslim son was a primary factor that led him to Islam. Although he had been interested in Islam for many years, he chose to delay his conversion until his parents passed away as not to hurt their feelings by becoming a Muslim. Also, another factor that supported his interest in Islam was observing his Muslim friends performing prayers. However, the role of media in the informant's conversion was not entirely irrelevant as he admitted that the talks of Dato' Ustaz Kazim Elias or also known as DUKE, were among the Islamic materials he consumed prior to becoming a Muslim. Therefore, the role of media in the informant's conversion may be supplementary as he treated DUKE's Islamic talks as additional materials to strengthen his faith in Islam.

Meanwhile, most informants from Brunei who were in their 20s admitted that books were the supplementary tools in their conversion to Islam. It was unexpected because this age group generally expected to rely on modern technology such as social media to gather information about Islam, but these young Bruneians opted for traditional media sources instead. The books were categorised into academic and non-academic materials. Schoolbooks or academic reading materials seemed to be the most popular media references among the informants probably because they finished school recently.

One informant disclosed that while studying Sociology in school, she came across books on comparative religions which helped her in choosing Islam:

\section{[Informant SR, Brunei]}

I had always wanted to be a Muslim, but at the time I was unable to convince my parents. At school, my friends would ask me to study about Islam more. In Sociology class, we learned to compare religions. From the books, I could see the beauty of Islam. [trans]

These books assisted the informant in her search of the beauty of Islam while some informants from Sabah and Sarawak perceived religious comparison as offensive. Informant SR was optimistic that Islam would be a better lifestyle for her than her old practice as a free-thinker. She did not specify the names of the books, but they are assumed to be academic books since she used them in the 
classroom. In addition, she was studying other Islamic subjects at the time, but the books on comparative religions caught her interest the most. This is probably because she was already interested in Islam and the books materialised the beauty of Islam to her and so she managed to convince her parents to bless her conversion to Islam.

Another informant confessed that he was interested in the religious subject taught in school. He particularly favoured the books on the stories of the prophets which were used during lessons:

\section{[Informant Q, Brunei]}

I had always liked the religious subject in school. I liked the books on the stories of the prophets. After I finished school, I joined the army, so I delayed my plan to convert. I let my mother and my aunt convert first. It was smooth since most of my family and relatives had converted to Islam long before me. [trans]

This again shows that media was not the primary influence in the informant's journey to become a Muslim. Nevertheless, the books of Seerah played a significant role for the 27 year old informant in supporting his decision to become a Muslim eventually. The stories of the prophets, as pointed out by some Sabah informants in the previous section, are the perfect examples of how people should live their lives. Furthermore, stories are easily digested by the converts as they combine all the Islamic elements like Figh and Tawheed. It is certainly more practical than learning these elements separately and so Seerah could be the best inception to learning about Islam in detail for the non-Muslims and new converts. Besides, the obstacles faced by the prophets and how they overcame them could reassure informants that all the problems in this world are temporary.

As for a 22-year old informant, the book that impacted him prior to becoming a Muslim was not an academic one; rather, it was a casual reading material titled Keindahan Agama Islam (The Beauty of Islam):

\section{[Informant AQ, Brunei]}

I was reading a book titled Keindahan Agama Islam shortly before conversion, but I cannot remember the name of the writer, but it was from Malaysia. It helped me understand the religion better. [trans]

Akin to some other informants, the informant was unable to recall the name of the author, implying that the contents of the books were more imperative than the persons who wrote them. Nevertheless, he admitted that the book gave 
him a further understanding of the beauty of Islam which reassured him that becoming a Muslim was the right decision. Even though it was not an academic book, it served the same purpose as the previous books mentioned. Moreover, the contents of these books were quite similar, but they are presented in different forms.

Meanwhile, two other informants used YouTube to search for more information about Islam. The difference is, however, to one informant, the search for Islam was initially unintentional as his friend suggested it:

\section{[Informant $\mathrm{KH}$, Brunei]}

A friend told me about him [Dr. Zakir Naik]. One day, I watched this video, some girls converted to Islam there and then. I did not know that he is the one my friend was talking about.

The informant's friend had suggested him to follow Dr. Zakir Naik for more information about Islam. Afterwards, while using YouTube, he stumbled upon the video of Dr. Zakir Naik and one non-Muslim reciting syahadah in front of the scholar and a large audience. Although the informant at the time was not aware that Dr. Zakir Naik was the person mentioned by his friend, the video sparked his interest in Islam. His curiosity and his Muslim cousin triggered the informant's fascination towards Islam, thus the video was considered a meaningful supplementary tool in his conversion.

On the other hand, a 21-year old informant stated that her search for Islamic information was intentional. Not only that, she utilised more than one media outlet as she believed she needed as much knowledge about the religion as possible before she embraced it:

\section{[Informant HZ, Brunei]}

I read books while in secondary school. I also searched for Islamic lectures on YouTube. More frequently I gained the information from Facebook, but I was extra careful not to fall for false information. [trans]

The use of different media outlets signified that the informant was not only dedicated in her decision to become Muslim but was supposedly more eager than the rest of the Bruneian informants in using both traditional and social media as platforms to search for Islamic information. The informant's uses of more than one medium were similar to one informant from Sarawak, Informant NR. The difference is the Sarawak informant encountered the Islamic contents in traditional media, radio and books. As opposed to the Brunei informant who was in her 20s, 
the Sarawak informant was in her 40s. That said, at the time of the Sarawak informant's conversion which was in the 1990s, social media such as YouTube and Facebook were not yet available. In regards to the Bruneian informant, Informant $\mathrm{HZ}$, her uses of multi-media references for her conversion could be because she studied Information Technology thus she was able to optimise the uses of media outlets. The books she read while in secondary school could be the introductory sources that nurtured her interest in Islam just like other Brunei informants who admitted school books played major roles prior to their conversions. She also displayed a sense of awareness of the risk of receiving Islamic information through social media, namely Facebook. Since the informant was a new convert, she requires extra caution as not to believe in false information pertaining to Islam.

\section{Theoretical Analysis}

In this current study, the media were involved in the informants' conversions as significant compliments. Furthermore, this present study concentrated on the influence of media in the Muslim converts' lives before they embraced Islam in Sabah, Sarawak and Brunei. Most of the informants in Sabah and Sarawak who converted in the 1980s and 1990s were older than the informants in Brunei who converted post-2000. The Islamic contents that the informants of Sabah and Sarawak consumed were mostly of traditional media such as books, television and radio. Other than that, Islamic materials were less available and less accessible in the 80s and 90s. Even though there were few Islamic contents at the time, in printed or broadcast, all of the informants managed to recall the most impactful Islamic contents they came across during their childhood or teenage years.

There are differences in the religious change between those who read Islamic books and those who watched or listened to Islamic programmes on broadcast media. The informants who read Islamic books were fully aware of their choices for reading the materials. It means that the informants were already interested in Islam when they decided to read more about the religion. As discussed in the Result and Discussion section above, the informants who mentioned books as the 'helpful' media were mostly teenagers and adults. It suggests that Islamic-based books offered in-depth clarifications about Islam than the contents in broadcast media.

Meanwhile, the informants who watched and listened to the Islamic programmes did not foresee that the contents would influence their decisions to become Muslims until they converted to Islam. Most of the informants who consumed the Islamic media texts in broadcast media were small children at the time. Even though they were superficially attracted to the features of the Islamic 
contents, the informants were too young to contemplate on their meanings and significance. It was only upon introspection and in hindsight that they realised that some Islamic values had been embedded in them from those early exposures. It was also likely that the informants would subsequently come across more Islamic content later on either incidentally or deliberately, and the cumulative effect was their eventual decision to convert.

In regards to social media as agents in the informants' religious change, they were only opted by two informants in Brunei. One case was accidental and the other one was intentional. Both informants admitted the Islamic materials they viewed on social media were impactful in their conversions. Social media are certainly easy to access, but they did not exist during the time of the conversions of most informants in this study. Otherwise, there would be more use of social media in the informants' conversions to Islam.

Nevertheless, as indicated in the result and analysis above, even most of younger informants in Brunei selected Islamic materials in traditional media as their reference prior to becoming Muslims. This highlights the importance of reliability in receiving information about religion, in this context, Islam. As pointed out earlier, traditional media are deemed more reliable because the production of the Islamic materials and the credibility of the Muslim preachers were highly selective. Social media, on the other hand, allows too much freedom for user-generated content which raises the question of reliability of those contents.

\section{Conclusion}

In summary, both traditional and social media are useful platforms for the Muslim converts to receive da'wah. However, in this study, it is found that traditional media, especially books, played more important roles in the informants' conversion to Islam - owing to the informants' ages and their respective time of conversion. Most of the media mentioned by the informants also acted as supplementary to the other factors that sparked their interest in Islam. Even though the media were supplementary, the Islamic contents in the media were significantly memorable to the informants. The informants admitted that the Islamic contents they consumed, either during childhood or adulthood, helped with their reassurances in becoming Muslims. Traditional media such as books, television and radio programmes are the most impactful outlets to the informants in this study, whereas YouTube and Facebook are the social media outlets meaningful to a few informants. 
On the whole, all the informants in Sabah, Sarawak and Brunei admitted that media played significant roles in their conversion to Islam. However, to most of the Sabah and Sarawak informants, media had been significant in supplying Islamic contents long before they realised they wanted to become Muslims. Whereas to the Brunei informants, media only became influential shortly after they decided to convert to Islam.

\section{References}

Asiyah az-Zahra Ahmad Kumpoh. (2014). Some insights into the impacts of the Islamic education on the non-Muslims in Brunei Darussalam. International Journal for Historical Studies, 5(2), 161-176

Badli Shah bin Alauddin. (2016). Seni dakwah kontemporari. Kuala Lumpur: Telaga Biru Sdn Bhd.

Esposito, J. L., \& Kalin, I. (2011). Introduction. In J. L. Esposito \& I. Kalin (Eds),

The challenge of pluralism in the $21^{\text {st }}$ century: Islamophobia (pp. xx1-xxxv).

Oxford: Oxford University Press.

Fadzli Adam, Marhana Mohamed Anuar, \& Ab. Hamid Ali. (2014). The use of the blog as a medium of Islamic Da'wah in Malaysia. International Journal of Sustainable Human Development, 2(2), 74-80.

Hassanal Harries. (2015, March 28). 2 families embrace Islam in conversion ceremonies. The Brunei Times. Retrieved from http://www.bt.com.bn/news-national/2015/03/28/2-families-embraceislam-conversion-ceremonies

Hjarvard, S. (2008). The mediatization of religion: A theory of the media as agents of religious change. Northern Lights, 6(1), 9-26.

Hoover, S. M. (1988). Mass media religion: The social resources of electronic churches. California: Sage Publications.

Kovačič, M. P., Erjavec, K., \& Štular, K. (2010). Credibility of Traditional vs Online News Media: A Historical Change in Journalists' Perceptions? Retrieved from hrcak.srce.hr/file/88479

Mohd. Adam Mahadi (2013). A case study of religious engagement online: How Malaysian Muslim students access Islamic information. Unpublished Master's thesis, The Rochester Institute of Technology, New York, United States.

Muhammad Yusuf Khalid, \& Wan Mohd. Fazrul Azdi Wan Razali. (2011). Reaching out to the non-Muslims: The challenges and the prospects of Islamophilia. Ulum Islamiyyah, 6, 29-57. 
Osman Abdullah @ Chuah Hock Leng. (2006). Methodology of Da'wah to the non-Muslim Chinese in Malaysia: A preliminary observation. Ulum Islamiyyah, 5(1), 65-93.

Rasidah HAB. (2012, May 13). Use new media to propagate Islam. The Brunei Times. Retrieved from http://www.bt.com.bn/newsnational/2012/05/13/use-new-media-propagate-islam

Salinayanti Salim. (2018). An exploration of media work of a convert Da i: Specific reference to Imam Suhaib Webb. Malaysian Journal of Media Studies, 20(1), 1-13

Severin, W. J., \& Tankard, J. W. (1979). Communication theories: Origins, methods, uses. New York: Hastings House.

Stout, D. A. (2012). Media and Religion: Foundations of an Emerging Field. New York: Routledge.

Umar Halim, \& Samsudin A. Rahim. (2010). Penglibatan digital: akses dan penggunaan e-agama dalam kalangan generasi muda Muslim. Jurnal Komunikasi Malaysia, 27(2), 121-135.

Zebiri, K. (2008). British Muslim converts: Choosing alternative lives. Oxford: Oneworld Publications.

Date of Received: $1^{\text {st }}$ October $2018 \quad$ Date of Accepted: 15 $5^{\text {th }}$ December 2019 